BMJ Paediatrics Open

\title{
Health needs of refugee children identified on arrival in reception countries: a systematic review and meta- analysis
}

\author{
Albertine Baauw, ${ }^{\ominus 1,2,3}$ Joana Kist-van Holthe, ${ }^{\circ 3}$ Bridget Slattery, ${ }^{1}$ \\ Martijn Heymans, ${ }^{4}$ Mai Chinapaw, ${ }^{3}$ Hans van Goudoever ${ }^{5}$
}

To cite: Baauw A, Kist-van Holthe J, Slattery B, et al. Health needs of refugee children identified on arrival in reception countries: a systematic review and metaanalysis. BMJ Paediatrics Open 2019;3:e000516. doi:10.1136/ bmjpo-2019-000516

- Additional material is published online only. To view please visit the journal online (http://dx.doi.org/10.1136/ bmjpo-2019-000516).

Received 11 May 2019 Revised 14 August 2019 Accepted 24 August 2019
Check for updates

\section{(c) Author(s) (or their} employer(s)) 2019. Re-use permitted under CC BY-NC. No commercial re-use. See rights and permissions. Published by BMJ.

For numbered affiliations see end of article.

\section{Correspondence to} Dr Albertine Baauw; a.baauw@ amsterdamumc.nl

\begin{abstract}
Background The worldwide number of refugees has considerably increased due to ongoing wars, national instability, political persecution and food insecurity. In Europe, about one-third of all refugees are children, an increasing number of which are travelling alone. There are often no systematic medical health assessments for these refugee children on entry in reception countries despite the fact that they are recognised as an at-risk population due to increased burden of physical and mental health conditions. We aimed to perform a systematic review of the literature to describe the health status of refugee children on entering reception countries.
\end{abstract}

Methods A systematic search of published literature was conducted using the terms refugee, immigrant or migrant, medical or health, and screening.

Results Of the 3487 potentially relevant papers, 53 population-based studies were included in this review. This systematic review showed that refugee children exhibit high estimated prevalence rates for anaemia (14\%), haemoglobinopathies $(4 \%)$, chronic hepatitis B $(3 \%)$, latent tuberculosis infection (11\%) and vitamin D deficiency $(45 \%)$ on entry in reception countries. Approximately onethird of refugee children had intestinal infection. Nutritional problems ranged from wasting and stunting to obesity. Conclusions Refugee children entering reception countries should receive comprehensive health assessments based on the outcomes of this systematic review, national budgets, cost-effectiveness and personal factors of the refugees. The health assessment should be tailored to individual child health needs depending on preflight, flight and postarrival conditions.

A paradigm shift that places focus on child health and development will help this vulnerable group of children integrate into their new environments.

PROSPERO registration number

122561.

\section{INTRODUCTION}

The global population of forcibly displaced persons has substantially increased over the last two decades (ie, from 37.3 million individuals in 1996 to 68.5 million in 2018). ${ }^{1}$ Throughout 2016, 1.2 million new refugees and asylum seekers (box 1) arrived in
Europe, thus increasing the total number of refugees living within the continent to just under 4.4 million. $^{2}$

This global humanitarian situation is complicated by the fact that approximately half of all refugees and asylum seekers worldwide are children. Eurostat numbers indicate that nearly 400000 children claimed asylum in Europe in 2016; $15.9 \%$ of these children were registered as unaccompanied minors. ${ }^{2}$ Country of origin, ethnicity and preflight conditions are all factors that contribute to the unique health risks of refugee children. Previous research has also shown that refugee children often have complex healthcare needs. ${ }^{3}$ The health status of many children residing in reception countries is known through antenatal screening, neonatal screening, immunisation programmes and regular medical follow-ups. However, this is often not the case for refugee children.

We aimed to systematically review the literature to describe the health status of refugee children on entering reception countries. Specifically to describe the prevalence of anaemia, haemoglobinopathies (HbP), infectious diseases, growth and nutrition disorders as identified through health screening programme and their vaccination status.

\section{HEALTH CONCERNS IN REFUGEE CHILDREN} Anaemia and genetic disorders of the red blood cells

Anaemia is a significant public health problem worldwide. A WHO global report revealed that children are prone to developing anaemia if they reside in a country with a high burden of infectious diseases, nutritional deficiencies or HbP. Among refugee children in Jordan in 2014, $48 \%$ of the children living in Zaatari refugee camp suffered from any kind of anaemia. Refugee children 


\section{Box 1 Definitions}

In this article, the term 'refugee children' is used to describe the entire child population of asylum seekers, refugees, status-holders and undocumented migrants. The term 'children from refugee and refugee-like backgrounds' is also widely used. There is no universally accepted term to describe refugee children.

Refugee: An asylum seeker that has fled their home country and has a 'well-founded fear of persecution' if they return home. Refugee status is granted when an asylum seeker has been acknowledged as a refugee according to the United Nations Refugee Convention. A refugee has completed the asylum process when they have been granted a residence permit. ${ }^{34}$

Asylum seeker: An individual who has left their home country and calls on the protection of another country and whose request for sanctuary has yet to be processed. ${ }^{35}$

Unaccompanied minor or unaccompanied minor refugee: An individual under the age of 18 applying for asylum without a relative older than 18 years of age. In the past, this group was also referred to as unaccompanied minor asylum seekers.

residing outside the camp were better off with $26 \%$ suffering from anaemia. ${ }^{4}$ For refugee children entering the USA, Yun et al found anaemia prevalence ranging from $6 \%$ to $23 \%$ depending on the country of origin, with the highest prevalence up to $35 \%$ in children less than 5 years of age. ${ }^{3}$ Similar results were found by Geltman $e t$ al among refugee children entering the Massachusetts between 1995 and 1998, with $12 \%$ of anaemia in the overall population and $28 \%$ in the group younger than 2 years. ${ }^{5}$ Anaemia increases the risk of child morbidity and mortality while also contributing to poor physical and cognitive development and performance. ${ }^{6}$ Disorders of

\section{Box 2 Study selection criteria}

Study inclusion criteria, grading and classification
Publication type:
Studies: observational, retrospective, prospective
Language: published in English
Study population:
- Refugee children from Africa, Asia or the Middle East
Age: reported results specific to children or adolescents (0-18 years)
- Medical screening on children's entry in reception countries
Sample size: minimum of 25 children
Study exclusion criteria
Publication type:
Guidelines
Surveillance registration
National notifiable disease reports
Case studies
Study population
Age not clearly defined
Results of children and adults combined
Screening of adoptees
Children attending curative services
Outbreak control
- Children from the Americas, Europe or the Western Pacific
Mental disorders in refugee children

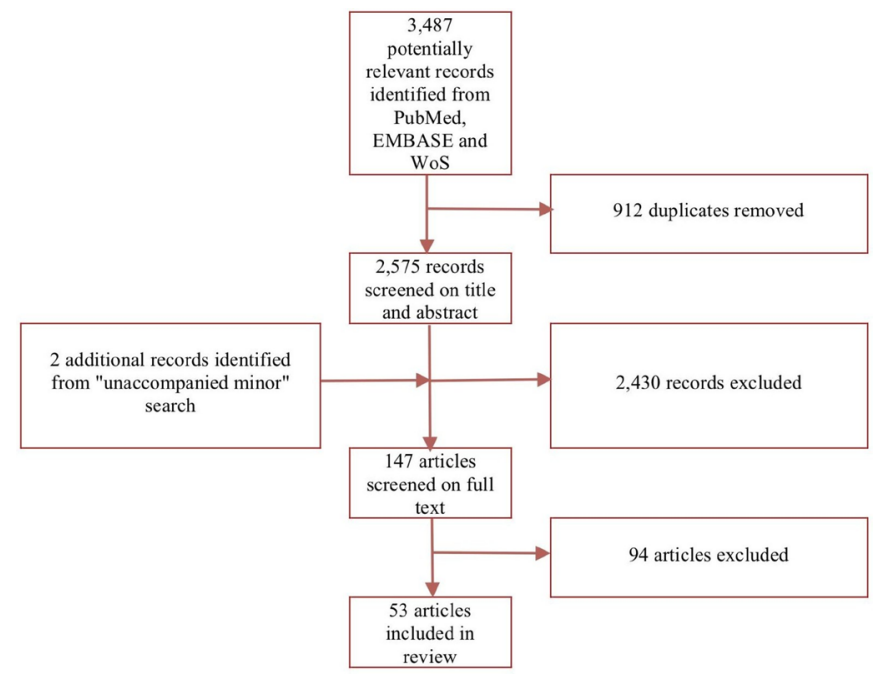

Figure 1 Flowchart selection process. WoS, Web of Science.

the red blood cells, HbP (eg, sickle cell disease), thalassemia and glucose-6-phosphate dehydrogenase (G6PD) deficiency are common genetic conditions in children originating from Africa, Asia and the Middle East. These disorders not only contribute to the development of anaemia in carriers, but they can also lead to severe diseases, adverse birth outcomes and lowered life expectancy rates. ${ }^{7}$ Hereditary and metabolic disorders are also responsible for a substantial number of infant morbidities and mortalities in Arab countries. A total of $60 \%$ of children born to Iraqi refugees settling in the USA had parents from the same ethnic group or who were consanguine; this may account for their high prevalence of inherited blood disorders (ie, G6PD (39.5/10000) and thalassemia $(10.5 / 10000)){ }^{8}$

\section{Infectious diseases}

Although the hepatitis B virus (HBV) disease can be prevented through vaccination, HBV infection remains a major public health problem globally. Perinatal infections with $\mathrm{HBV}$ in children result in chronic $\mathrm{HBV}$ infections in $90 \%$ of all cases; additionally, $25 \%$ of these affected children will develop primary liver cancer or cirrhosis as adults. The estimated global prevalence of the disease is $3 \%{ }^{9}$ However, there is wide regional variation in this number also seen in refugee children. ${ }^{9}{ }^{10}$ Chronic hepatitis B infection was found in $4 \%$ of refugee children attending a specialist health clinic in Sydney and in $8 \%$ of the unaccompanied minor refugees in Germany. ${ }^{10}{ }^{11}$ The Joint UnitedNations Programme on HIV and AIDS estimate indicated that approximately 1.8 million children under the age of 15 were living with HIV. Prevalence data for HIV among refugee children are scarce because HIV testing is not routinely performed. Circumstantial evidence from the Netherlands were 80 out of 4854 pregnant asylum-seeking women were found to be living with HIV in the period from 2000 to 2008. Among African pregnant women, the prevalence rate was $3.4 \%$ 


\begin{tabular}{lcc}
\hline Table 1 & Reception countries of refugee children \\
\hline Countries & Studies & $\mathbf{n = 2 2 3 0 3 7}$ \\
\hline Australia & 8 & 3497 \\
Canada & 4 & 1361 \\
Germany & 6 & 3816 \\
Malta & 1 & 277 \\
New Zealand & 2 & 763 \\
Spain & 2 & 373 \\
Netherlands & 2 & 257 \\
UK & 2 & 34197 \\
USA & 26 & 178496 \\
\hline
\end{tabular}

compared with $0.04 \%$ in women from other regions. Women arriving without a partner and unaccompanied minors had higher HIV prevalence rates. ${ }^{12}$

Tuberculosis (TB) is one of the leading worldwide causes of death from infectious disease. The disease is steadily declining in most Western countries, but migration, poverty, war and political instability provide a perfect breeding ground for its resurgence. ${ }^{13}$ Twenty-five per cent of the refugee children entering Massachusetts between 1995 and 1998 had a positive skin test for latent $\mathrm{TB}$ and $21 \%$ of these children were found with intestinal parasites. $^{5}$

\section{Growth and nutrition}

In 2014, little evidence was found for severe acute malnutrition in Syrian refugee children in a Jordan refugee camp. ${ }^{414}$ Growth abnormalities among recently arrived refugee children are common, showing both growth retardation and overweight and obesity. ${ }^{5}$

\section{Vaccine coverage}

Although vaccine uptake has increased on a worldwide scale as U5 mortality has decreased, there has been a resurgence of vaccine-preventable diseases such as measles, polio and diphtheria among refugee children in war zones and other unstable areas. ${ }^{11}$

\section{METHODS}

\section{Search strategy and eligibility criteria}

This systematic review was performed and reported according to Preferred Reporting Items for Systematic Reviews and Meta-Analyses guidelines. ${ }^{15}$ We conducted a systematic search for published articles related to the study intent in PubMed, EMBASE and the Web of Science database between 1 January 2007 and 1 April 2018. We developed a search strategy that was adapted for each database using a combination of medical subject headings, including terms related to refugee/migrant/immigrant, medical/health and screening. We supplemented this search by using the controlled term 'unaccompanied minor' in all three databases.

Three reviewers $(\mathrm{AB}, \mathrm{BS}$ and $\mathrm{JKvH})$ independently screened all search results and systematically reviewed the retrieved records by applying the eligibility criteria (box 2).

All articles identified as relevant by all three researchers were reviewed in full by two researchers (AB and $\mathrm{BS}$ ) to determine whether they met the inclusion criteria.

Observational studies on health status among the general population of refugee children entering reception countries were considered for inclusion in this systematic review. The inclusion and exclusion criteria are shown in box 2. Mental health disorders were excluded because such a review requires a different approach. Studies were also excluded if they reported on prevalence rates among high-risk populations (eg, children whose health status was checked during hospital admission, screened during outbreaks or selected for screening through contact tracing (eg, hepatitis B and active TB)). The selection process is outlined in a flowchart in figure 1 .

All selected studies were qualitatively assessed by applying a checklist of methodological quality adapted from the Dutch Cochrane Centre (see online supplementary tables S1 and S2). The representativeness of study data was assessed for all studies conducted among minority groups (including ethnic minorities) or in specific locations (see online supplementary table S2).

\section{Data analysis}

We extracted the following types of data from each article: study characteristics (eg, study type and country), participant characteristics (eg, age, age range and region) and one or more of several tests (including laboratory tests and cut-points, ie, those for anaemia, genetic disorders of the red blood cells, infectious diseases, growth and nutrition, and vaccination status). Descriptive analyses and separate prevalence rates were performed using IBM SPSS V.23. All eligible articles were subjected to a meta-analysis. Prevalence rates according to health status and country of origin were also meta-analysed. A Freeman-Tukey double arcsine transformation of prevalence data was applied before pooling and back-transforming the results. A random effects model was used for all pooled prevalence rates. Forest plots were created to show the prevalence of each study and overall pooled prevalence (online supplementary file 1). Meta-analyses were conducted in R V.2.2 (Ref: R Core Team (2017). R: A language and environment for statistical computing. R Foundation for Statistical Computing, Vienna, Austria. URL: https://www.R-project.org/).

\section{RESULTS}

Our systematic review included 53 articles that, when combined, conducted research on a total of 223037 refugee children who entered one of nine reception countries from a point of origin in either Africa, Asia or the Middle East (table 1). The highest number of reports were available from the USA $(n=26)$. Data from five 
Open access

Table 2 Regions of origin, reception countries and reported conditions of refugee children

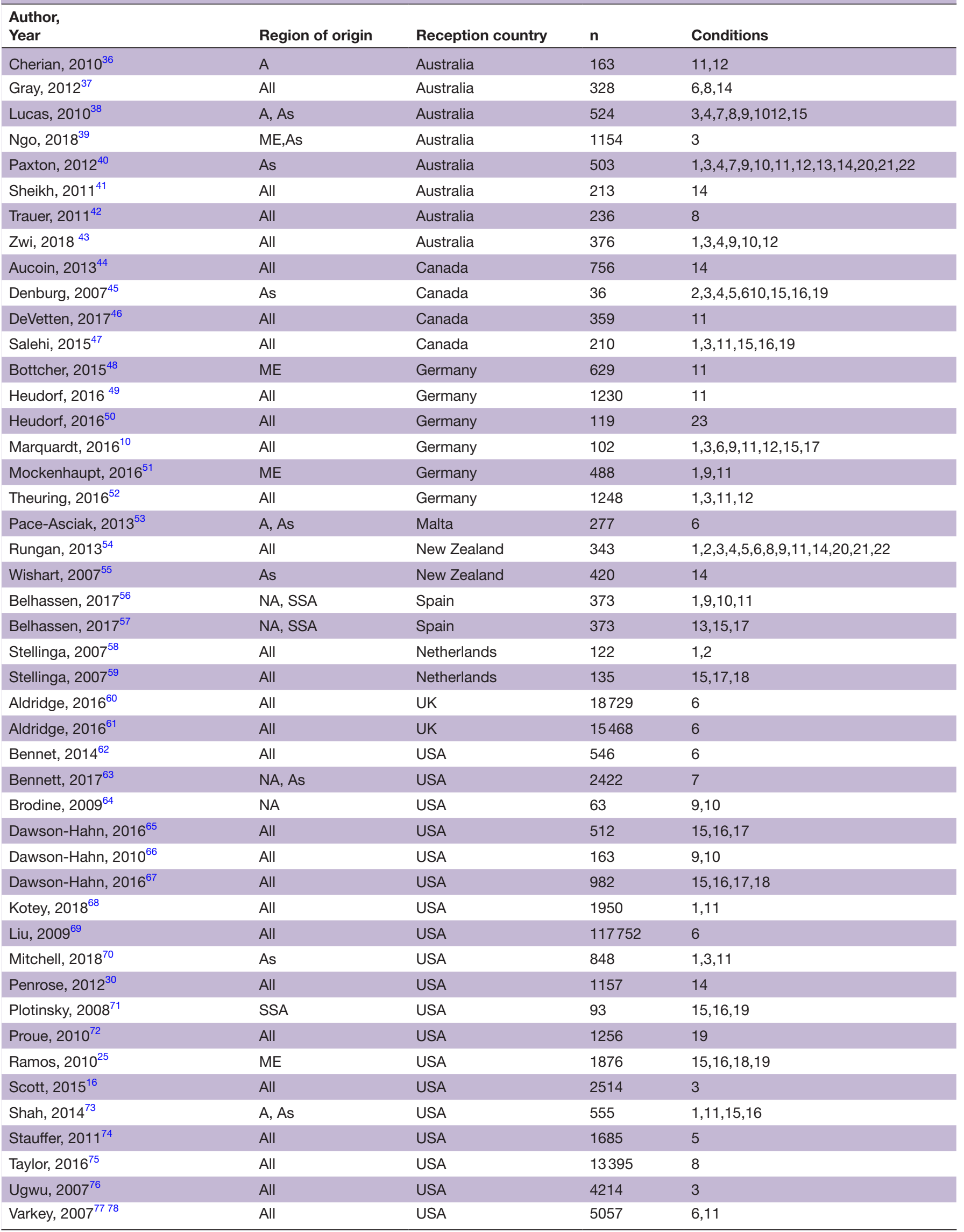

Continued 
Table 2 Continued

\begin{tabular}{lllll}
\hline $\begin{array}{l}\text { Author, } \\
\text { Year }\end{array}$ & Region of origin & Reception country & $\mathbf{n}$ & Conditions \\
\hline Varkey, $2007^{78}$ & All & USA & 4699 & 8 \\
\hline Walker, $2011^{79}$ & As & USA & 27 & 13 \\
\hline Walters, $2016^{80}$ & All & USA & 407 & 3 \\
\hline Yanni, $2013^{81}$ & ME & USA & 5734 & $2,15,17,18$ \\
\hline Yun, $2016^{3}$ & All & USA & 2291 & $1,3,7,8,10,19$ \\
\hline Yun, $2016^{16}$ & All & USA & 8148 & $3,8,22$ \\
\hline Zabel, $2017^{82}$ & A, As & USA & 150 & 19 \\
\hline
\end{tabular}

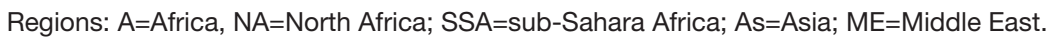

Conditions: $1=$ =anaemia; $2=$ haemoglobinopthy; $3=$ hepatitis B virus; $4=$ hepatitis $C$ virus; $5=H I V ; 6=$ active TB; $7=$ latent tuberculosis (TB) (interferonyrelease assay); $8=$ latent TB (Mantoux); $9=$ schistosomiasis; 10=strongyloides; 11=intestinal infections; $12=$ malaria; 13=vitamin $B_{12}$ deficiency; $14=$ itamin D deficiency; 15=wasting; $16=$ =stunting; $17=$ =verweight; $18=$ obesity; $19=$ =elevated blood lead level; $20=$ immunity for rubella; $21=$ immunity for measles; 22=immunity for hepatitis B.

European countries accounted for a total of 13 studies. Most data were available from children who originally lived in Asia or Africa. When available, data from Africa were divided into two regional blocks (ie, North African countries and sub-Saharan countries).

Some articles reported on a single condition seen in refugee children, while others reported on screening procedures related to several conditions at once (table 2).

Estimates of the prevalence rates for health conditions among refugee children arriving in Australia, Canada, Germany, Malta, New Zealand, Spain, the Netherlands, the UK and the USA are presented in table 3 . We found 14 studies that reported on anaemia, with a pooled prevalence rate of $14 \%$. The global pooled prevalence rate for chronic $\mathrm{HBV}$ is estimated at $3 \%$. Most data on infectious diseases originated from national screening programmes for TB. Latent TB was found to be highly prevalent among refugee children. This overview also showed that one-third of refugee children had intestinal infections. Data on growth, nutrition and micronutrient deficiencies revealed that a high percentage of children were suffering from vitamin $\mathrm{D}$ deficiencies.

Tables 4-8 present health conditions among refugee children according to their region of origin. Forest plots are presented in the online supplementary file 1 .

\section{Anaemia and genetic disorders of the red blood cells}

The estimated prevalence of anaemia according to region is presented in table 4. African refugee children under the age of 19 constituted the population most affected. The prevalence of anaemia was found to decrease with age; consequently, children under five were the most prone to anaemia. ${ }^{3}$ Adolescents from Syria were the least affected. Data on HbP were scarce and represented a wide variety of $\mathrm{HbP}$ (eg, sickle cell disease, sickle cell trait, thalassemia and G6PD).

\section{Infectious diseases}

Estimates on the burden of infectious disease by region are presented in table 5. The rate of chronic HBV among refugee children was based on 16 reports representing a total of 19196 subjects. We also divided this rate according to age group. HBsAg seroprevalences among refugee children originating from Africa, Asia and the Middle East are reported in table 6. The highest rates of prevalence were found in African countries, with a higher intermediate endemicity (HBsAg prevalence $5 \%-7.99 \%$ ) in sub-Saharan Africa. On average, children from the Asian region had a lower intermediate endemicity (HBsAg prevalence 2\%-4.99\%). HBsAg seroprevalences in Asia increased with age (table 6). Higher intermediate endemicity was found in children originating from Asia in the 12-s19age group. The lowest rate of endemicity was found in children from the Middle East (HBsAg prevalence $\leq 2 \%$ ). Based on the only available report, the highest endemicity of chronic HCV was found in Africa. Positive serology can be an indicator for both past or active infection and requires further evaluation. Results from three of the four studies on HIV indicated that no participating children were HIV positive. While refugee health assessments are widely implemented in the USA, testing on HIV is not routinely performed in children under the age of 15. Since 2010, HIV testing has only been performed among refugees suspected of the infection.

Data on active TB among refugee children were available from national screening programmes in the USA and the UK. For the majority of articles, data were presented as a single group and could not be broken down by age or traced to the child's region of origin. An age breakdown was thus not possible. The highest prevalence of latent TB $(16 \%)$ was found in children originating from sub-Saharan Africa. This prevalence increased with age. A high endemicity for schistosomiasis and Strongyloides seroprevalence was found in African children, mainly those originating from the sub-Saharan region. Positive serology can be a sign of past or present infection. The 15 studies on intestinal infections were conducted among a total of 12723 refugee children. Here, an estimated $31 \%$ were infected with at least one pathogen. The main reservoir of intestinal infection was found in U5 children. 
Table 3 Estimated prevalences (\%) and $95 \% \mathrm{Cl}(\%)$ of selected conditions among refugee children 0-18 years from all regions on entry in reception countries

$\begin{array}{lll}\text { Prevalence estimates, } \% 95 \% \mathrm{Cl} & \text { Studies, } \mathrm{n} & \text { Participants, } \mathrm{n}\end{array}$

Anaemia and genetic disorders of the red blood cells

\begin{tabular}{|c|c|c|c|c|}
\hline Anaemia & 13.7 & (8.7 to 19.7 ) & 14 & 14632 \\
\hline Haemoglobinopathy & 3.7 & (0.2 to 10.5$)$ & 4 & 5400 \\
\hline \multicolumn{5}{|l|}{ Infectious diseases } \\
\hline Hepatitis B & 2.6 & (1.6 to 3.7 ) & 16 & 19196 \\
\hline Hepatitis C & 0.2 & (0.0 to 1.2$)$ & 5 & 1415 \\
\hline HIV & 0.03 & (0.00 to 0.25$)$ & 4 & 2165 \\
\hline Active TB & 0.2 & (0.0 to 0.5$)$ & 10 & 162100 \\
\hline LTBI (IGRA) & 11.3 & (9.4 to 13.3 ) & 4 & 3291 \\
\hline LTBI (Mantoux) & 19.3 & (11.0 to 29.3 ) & 8 & 33317 \\
\hline Schistosomiasis & 9.5 & (5.6 to 14.4 ) & 10 & 3292 \\
\hline Strongyloides & 10.4 & (4.8 to 17.7 ) & 8 & 3793 \\
\hline Intestinal infections & 31.0 & (22.1 to 40.6 ) & 15 & 12723 \\
\hline Malaria & 2.58 & (0.7 to 5.4$)$ & 6 & 2408 \\
\hline \multicolumn{5}{|c|}{ Growth, nutrition and micronutrient deficiencies and lead poisoning } \\
\hline Vitamin B deficiency & 0.6 & $(0.1$ to 1.5$)$ & 3 & 752 \\
\hline Vitamin D deficiency & 44.6 & (27.7 to 62.2$)$ & 7 & 3715 \\
\hline Wasting & 8.8 & (6.5 to 11.4$)$ & 15 & 9167 \\
\hline Stunting & 17.2 & (9.4 to 26.5$)$ & 7 & 2293 \\
\hline Overweight & 10.8 & (7.6 to 14.3$)$ & 6 & 7838 \\
\hline Obesity & 5.7 & (1.9 to 11.4$)$ & 4 & 8538 \\
\hline Elevated blood lead level & 6.1 & (2.4 to 11.0$)$ & 8 & 5898 \\
\hline \multicolumn{5}{|l|}{ Vaccine coverage } \\
\hline Immunity for rubella & 72.4 & (45.3 to 92.9 ) & 2 & 256 \\
\hline Immunity for measles & 70.2 & (30.7 to 97.2$)$ & 2 & 402 \\
\hline Immunity for hepatitis B & 63.0 & (51.1 to 74.2$)$ & 3 & 1802 \\
\hline
\end{tabular}

Anaemia was defined as a haemoglobin level below the age-specific and gender-specific cut-points established by the WHO or the US Centres for Disease Control and Prevention. Haemoglobinopathy included sickle cell disease, sickle cell trait, thalassemia and glucose-6-phosphate dehydrogenase deficiency. Hepatitis B was defined as HBsAg seropositive. Hepatitis C virus (HCV) infection was defined by the presence of antibodies for hepatitis C. HIV test includes the pre-entry screening on HIV in the USA. Active tuberculosis (TB) was defined as a positive chest X-ray and/or positive sputum. Latent tuberculosis infection (LTBI) was defined as a positive interferon-y release assay (IGRA) or a Mantoux tuberculin skin test $\geq 10 \mathrm{~mm}$. Schistosomiasis and strongyloides were defined by the presence of antibodies against schistosomiasis and Strongyloides stercoralis. Intestinal infections: at least one positive stool sample: ova, parasite tests or bacteriology tests. Vitamin D: insufficiency $26-50 \mathrm{~mol} / \mathrm{L}$ 25-hydroxyvitamin D; deficient $13-25 \mathrm{nmol} / \mathrm{L}$ and severely deficient $<13 \mathrm{nmol} / \mathrm{L}$. Growth tunting: $<5$ th percentile of body mass index for age, WHO. Stunting: height for age $<5$ th. Lead intoxication is defined as $>10 \mu \mathrm{g} / \mathrm{dL}$.

Table 4 Estimated prevalences and $95 \% \mathrm{Cl}(\%)$ of anaemia and haemoglobinopathies among migrant and refugee children by region of origin

\begin{tabular}{|c|c|c|c|c|c|c|}
\hline Region & All regions & Africa All & North Africa & $\begin{array}{l}\text { Sub-Saharan } \\
\text { Africa }\end{array}$ & Asia & Middle East \\
\hline \multicolumn{7}{|l|}{ Blood disorders } \\
\hline Anaemia & $13.7 \%$ & $21.7 \%$ & $11.3 \%$ & $7.9 \%$ & $14.1 \%$ & $5.0 \%$ \\
\hline $95 \% \mathrm{Cl}$ & (8.7 to 19.7 ) & & (0.5 to 32.0$)$ & (5.4 to 10.8$)$ & (4.2 to 28.5 ) & (0.7 to 12.6$)$ \\
\hline Studies & 14 & 1 & 2 & 2 & 4 & 4 \\
\hline $\mathrm{n}$ & 14632 & 83 & 3385 & 396 & 5060 & 2170 \\
\hline Haemoglobinopathy & $3.7 \%$ & $7.3 \%$ & & & $16.0 \%$ & $0.1 \%$ \\
\hline $95 \% \mathrm{Cl}$ & (0.2 to 10.5$)$ & & & & (8.0 to 26.0 ) & \\
\hline Studies & 4 & 1 & 0 & 0 & 2 & 1 \\
\hline $\mathrm{n}$ & 5400 & 41 & & & 68 & 4899 \\
\hline
\end{tabular}




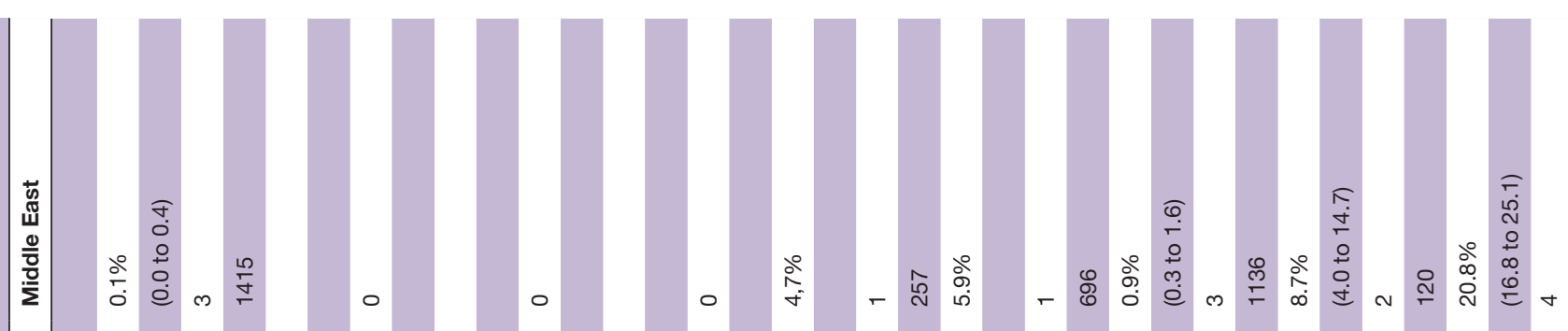

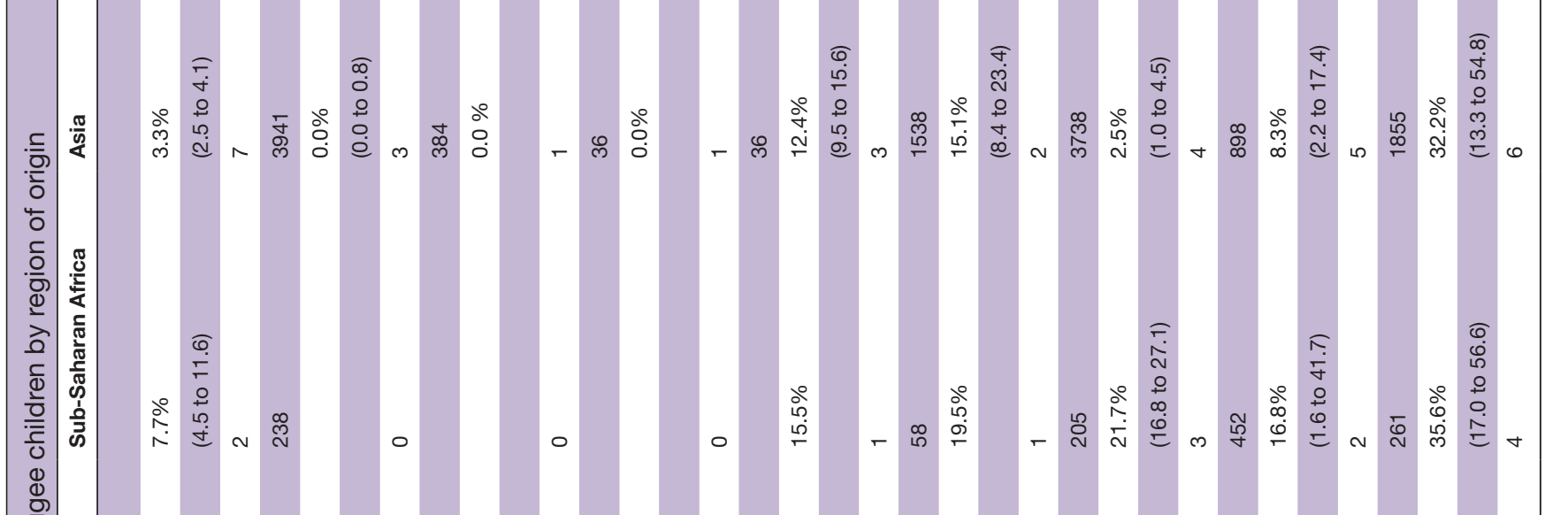

$\stackrel{\frac{\infty}{2}}{\frac{3}{2}}$

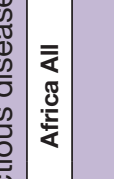
ㄸo
突

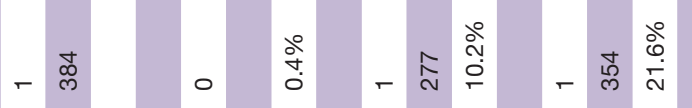

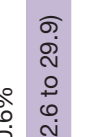

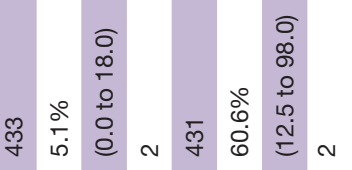

产

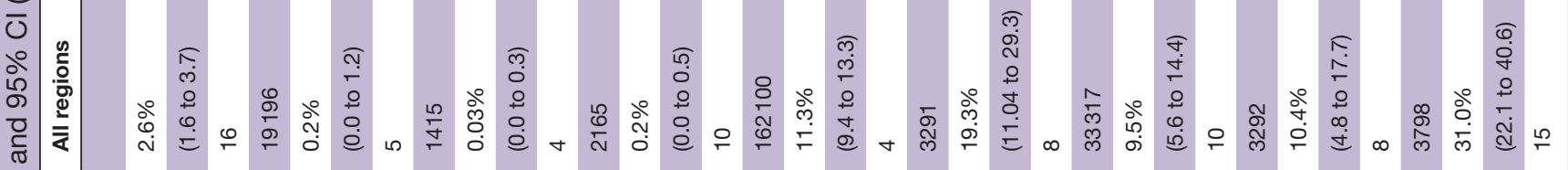

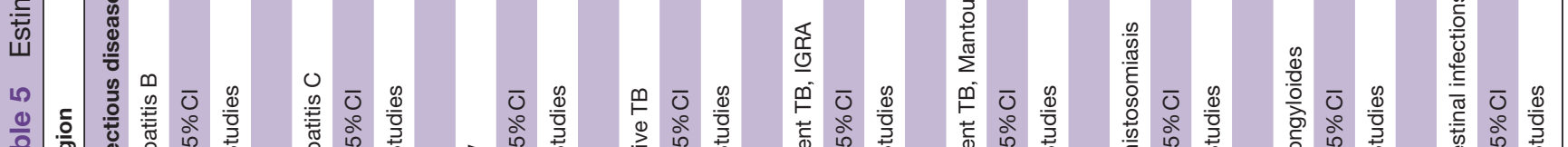

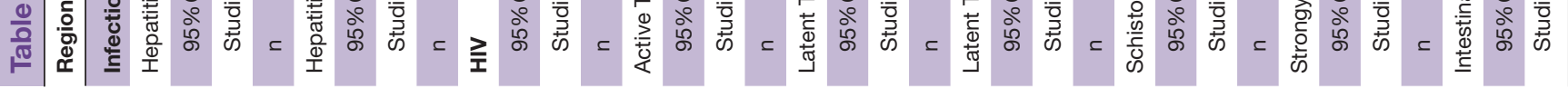

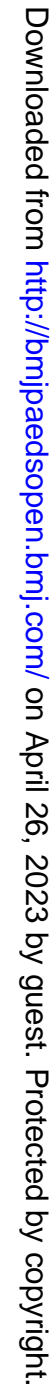




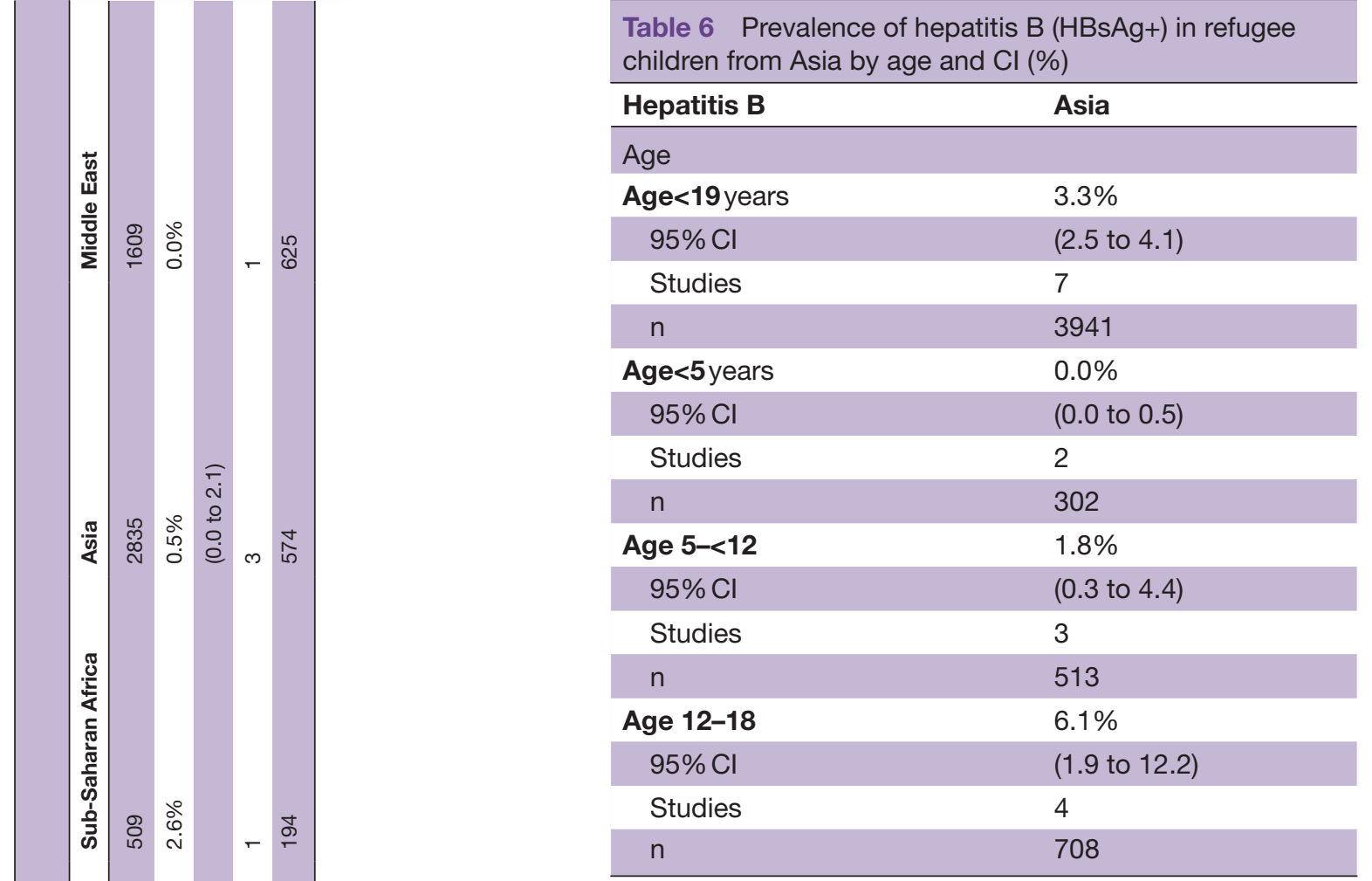

Refugee children bound for resettlement in the USA are given presumptive treatment. This contributes to a significant reduction in the prevalence of helminthiasis according to studies conducted on refugees after arrival in the USA. Refugee children from Africa showed the highest prevalence of malaria parasites.

\section{Growth, nutrition, and micronutrient deficiencies}

Up to $70 \%$ of all children from the Middle East that were studied were found to be 25-hydroxyvitamin D insufficient. Adolescents exhibited the highest prevalence of this insufficiency. Poor nutrition was evident through the presence of both underweight and overweight refugee children. A total of $11 \%$ of refugee children were reported as overweight, while $6 \%$ were classified as obese (table 7).

\section{Immunity against vaccine-preventable diseases}

Few data were available to estimate the rate of immunity against vaccine-preventable diseases (table 8). Yun's study indicated that HBV immunity increased with age, which was parallel to a decrease seen in the overall prevalence rate. $^{16}$

\section{DISCUSSION}

This systematic review showed that refugee children entering Australia, Canada, Germany, Malta, New Zealand, Spain, the Netherlands, the UK and the USA face considerable health risks. Various factors influence the risk of disease in this population, including the lack of access to antenatal screening, vaccination programmes and healthcare in addition to political instability, war, 
Table 7 Estimated prevalences and 95\% $\mathrm{Cl}(\%)$ of micronutrient deficiencies, growth and EBLL among migrant and refugee children by region of origin

\begin{tabular}{|c|c|c|c|c|c|c|}
\hline Region & All regions & Africa All & North Africa & $\begin{array}{l}\text { Sub-Saharan } \\
\text { Africa }\end{array}$ & Asia & Middle East \\
\hline \multicolumn{7}{|c|}{ Micronutrient deficiencies } \\
\hline Vitamin B & $0.6 \%$ & & & & $1.1 \%$ & \\
\hline $95 \% \mathrm{Cl}$ & (0.1 to 1.5$)$ & & & & & (8.49 to 16.96$)$ \\
\hline Studies & 3 & & & & 1 & \\
\hline $\mathrm{N}$ & 752 & & & & 352 & \\
\hline Vitamin D & $44.6 \%$ & $54.1 \%$ & & & $42.4 \%$ & $70.1 \%$ \\
\hline $95 \% \mathrm{Cl}$ & (27.7 to 62.2$)$ & (40.8 to 67.1 ) & & & (31.7 to 53.4$)$ & (60.6 to 78.8 ) \\
\hline Studies & 7 & 2 & & & 3 & 2 \\
\hline $\mathrm{N}$ & 3715 & 395 & & & 726 & 100 \\
\hline \multicolumn{7}{|l|}{ Growth } \\
\hline Wasting & $8.8 \%$ & $17.2 \%$ & $26.9 \%$ & $9.7 \%$ & $13.9 \%$ & $10.8 \%$ \\
\hline $95 \% \mathrm{Cl}$ & (6.5 to 11.4 ) & (2.1 to 42.2 ) & & (1.6 to 22.9 ) & (6.4 to 23.7 ) & (7.1 to 15.1$)$ \\
\hline Studies & 12 & 2 & 1 & 2 & 3 & 3 \\
\hline $\mathrm{N}$ & 9167 & 630 & 67 & 343 & 303 & 6321 \\
\hline Stunting & $17.2 \%$ & $20.6 \%$ & & $48.4 \%$ & $38.3 \%$ & $5.7 \%$ \\
\hline $95 \% \mathrm{Cl}$ & (9.4 to 26.5$)$ & & & & (31.5 to 45.5 ) & (2.9 to 9.4 ) \\
\hline Studies & 7 & 1 & 0 & 1 & 2 & 2 \\
\hline $\mathrm{N}$ & 2293 & 219 & & 93 & 190 & 594 \\
\hline Overweight & $10.76 \%$ & $5.93 \%$ & $19.40 \%$ & $15.60 \%$ & $7.14 \%$ & $12.42 \%$ \\
\hline $95 \% \mathrm{Cl}$ & (7.64 to 14.34$)$ & & & & & (8.49 to 16.96$)$ \\
\hline Studies & 6 & 1 & 1 & 1 & 1 & 2 \\
\hline $\mathrm{N}$ & 7838 & 219 & 67 & 250 & 154 & 5999 \\
\hline Obesity & $5.7 \%$ & $5.9 \%$ & & & $3.3 \%$ & $7.1 \%$ \\
\hline $95 \% \mathrm{Cl}$ & (1.9 to 11.4 ) & & & & & (1.8 to 15.4 ) \\
\hline Studies & 4 & 1 & 0 & 0 & 1 & 3 \\
\hline $\mathrm{N}$ & 8538 & 219 & & & 154 & 7686 \\
\hline \multicolumn{7}{|c|}{ Lead poisoning } \\
\hline EBLL & $6.1 \%$ & $6.0 \%$ & $1.5 \%$ & $11.6 \%$ & $3.7 \%$ & $1.4 \%$ \\
\hline $95 \% \mathrm{Cl}$ & (2.4 to 11.0$)$ & & & (0.0 to 37.8 ) & (0.2 to 10.2$)$ & (0.6 to 2.5 ) \\
\hline Studies & 8 & 1 & 1 & 2 & 3 & 2 \\
\hline $\mathrm{N}$ & 5898 & 790 & 584 & 157 & 1761 & 653 \\
\hline
\end{tabular}

EBLL, elevated blood lead level.

poverty, poor hygiene and insufficient nutrition in their countries of origin. This study revealed the heterogeneous nature of the population of refugee children as demonstrated by the wide variation in the estimated prevalence rates of a range of health conditions.

The global prevalence rates of chronic hepatitis found by Schweitzer et al are in line with this study's findings, which indicate that children originating from high-prevalence countries should be considered as at higher risk than children born in reception countries. ${ }^{9}$

There is a wide variety of national policies for screening refugee children on arrival. ${ }^{17}$ Policy statements emphasise the importance of multisector collaboration and child rights-based approaches. ${ }^{18}$
The European Association of Paediatrics has developed a practical, consensus-based recommendation for providing medical care to refugee children in Europe. ${ }^{19}$ Several clinical guidelines have been designed to address the health needs of both immigrants and refugees. The European Commission has developed a health assessment guideline for refugees and migrants entering European countries, including a section on child health and development. ${ }^{20}$ The US Centres for Disease Control and Prevention has similarly developed screening guidelines for immigrants (including refugee children) that are unique to each country of origin. ${ }^{21}$ Australian guidelines focus on infectious and non-infectious diseases ${ }^{22}$ Canada has also established extensive guidelines for the general 
Table 8 Estimated prevalences (\%) and $95 \% \mathrm{Cl}(\%)$ of immunity for vaccine preventable disease among migrant and refugee children by region of origin (references online)

\begin{tabular}{|c|c|c|c|c|c|c|}
\hline Region & All regions & Africa All & North Africa & $\begin{array}{l}\text { Sub- } \\
\text { Saharan } \\
\text { Africa }\end{array}$ & Asia & $\begin{array}{l}\text { Middle } \\
\text { East }\end{array}$ \\
\hline \multicolumn{7}{|c|}{ Immunity for vaccine preventable diseases } \\
\hline Immunity for rubella & $72.4 \%$ & & & & $84.6 \%$ & \\
\hline $95 \mathrm{Cl}$ & (45.3 to 92.9$)$ & & & & & \\
\hline 256 & 2 & 0 & 0 & 0 & 1 & 0 \\
\hline $\mathrm{N}$ & 256 & & & & 59 & \\
\hline Immunity measles & $70.2 \%$ & & & & $86.8 \%$ & \\
\hline $95 \% \mathrm{Cl}$ & (30.7 to 97.2$)$ & & & & & \\
\hline Studies & 2 & 0 & 0 & 0 & 1 & 0 \\
\hline $\mathrm{N}$ & 402 & & & & 228 & \\
\hline Immunity hepatitis B & $63.0 \%$ & & & & $50.2 \%$ & \\
\hline $95 \% \mathrm{Cl}$ & (51.1 to 74.2$)$ & & & & & \\
\hline Studies & 3 & 0 & 0 & 0 & 1 & 0 \\
\hline $\mathrm{N}$ & 1802 & & & & 241 & \\
\hline
\end{tabular}

refugee population to cover four areas of screening (infectious disease, mental health, chronic and non-communicable disease, and reproductive health). ${ }^{23}$ The Canadian Paediatric Society has likewise tailored these guidelines based on the country of origin when dealing with children. ${ }^{24}$ There are also countries with voluntary upon-entry medical screening for refugee children. A wide variety of practices are implemented in these cases, most of which are based on fragmented and sometimes limited experience or expert opinion.

Infectious diseases have traditionally been the priority of health assessment of refugee children. Due to the shift in disease burden in refugee populations, the focus of the health assessment of refugee children has moved towards early detection of more chronic and lifestyle conditions such as obesity. ${ }^{25}$

Decisions on how, for whom and when to extend health assessments with additional tests do not solely depend on estimated prevalence rates and the probabilities of developing certain health conditions but also on outside practicalities. These include national budgets, cost-effectiveness, the reversibility of certain conditions, minority access to health systems and knowledge of health conditions among healthcare workers.

The question of cost-effectiveness is an issue that can only be answered when data specifically for refugee children are available. Veldhuijzen et al proved that adult refugee screening programmes for chronic HBV were cost-effective when the goal was to improve outcomes through early detection and treatment. ${ }^{26}$ Usemann et $a l$ stated that LTBI screening is cost-effective if progression rates of $5 \%$ and higher from latent to active $\mathrm{TB}$ are present in populations with an LTBI prevalence of $14 \% .{ }^{27}$

Ethical questions surrounding screening programme for vulnerable groups must be considered. The screening criteria originally laid out by Wilson and Jungner provide a widely accepted framework for screening programmes. ${ }^{28}$

Another factor influencing the successful implementation of a comprehensive health assessment is the ability of healthcare professionals to provide culturally competent care. This includes ensuring the familiarity of healthcare providers with the culturally dependent presentation of symptoms and working to augment the fragmented or limited knowledge of the health risks and specific (tropical) diseases seen in refugee children. $^{29}$

Some conditions may spontaneously resolve after the migration process, when children are no longer continuously exposed to infectious diseases and when they receive access to proper micronutrients. However, Penrose et al showed that vitamin D levels worsened after refugees resettled in Western countries. ${ }^{30}$

Refugee children and their families are known to have poorer access to healthcare facilities than other groups. ${ }^{29}$ Several studies have underlined the importance of professional translators when attempting to improve medical outcomes among refugee children. ${ }^{31} 32$ Many refugees are already familiar with screening processes such as the premarital test for $\beta$-thalassemia. ${ }^{8}$ Brandenberger et al underlined in their review the three key challenges in healthcare delivery for refugees and migrants: communication, continuity of care and confidence. ${ }^{33}$

Issues such as granted access to care, follow-ups, economic aspects, feasibility and sustainability also need to be addressed before implementing an extended health assessment. These are beyond the scope of this systematic review. Rigorous qualitative evaluations of all children identified with a health condition should also be conducted to ensure they receive high quality care. 
Strengths and limitations of this systematic review

One strength of this systematic review was the overwhelming amount of population-based data that were available for use when analysing refugee children. However, the heterogeneity of their populations was the main limitation of this review. Unpredictable and fluctuating refugee streams and the ever-changing demographics in their countries of origin were also major limitations. The data do not necessarily reflect the current situations of conflict in the Middle East and Northern Africa, which cause rapid changes in refugee flows. The representativeness of the studied samples was also a major limitation. Therefore, we used the term estimated prevalence to describe our results. Thus, there may have been underestimates or overestimates. Prevalence rates may also vary due to introduction of new vaccination campaigns as evidenced by the declining prevalence of HBV over the last decade. We realise that our focus on English literature meant that relevant studies published in other languages would be missed.

\section{CONCLUSION}

Refugee children have considerable health risks on entry in reception countries. Thus, their health needs may be inadequately addressed. The results of this systematic review could be incorporated in multidisciplinary guideline development for comprehensive health assessments of refugee children tailored to the individual health needs of these children by considering their specific health risks, including those related to preflight conditions in their home countries and migration history.

This systematic review showed that we should consider a transition towards a child health-needs approach. A paradigm shift that places focus on child health and development will help this vulnerable group of children integrate into their new environments. This is critical from a governmental perspective considering many refugee children will ultimately be granted residency. Targeted health assessments on entry will assist them in gaining better access to healthcare while facilitating their familiarisation with healthcare rights. We hope this systematic review will inspire policy makers in the public health sector to pivot from national programmes designed to control infectious diseases towards health assessment procedures that focus on child health needs for the betterment of this vulnerable group of children.

\author{
Author affiliations \\ ${ }^{1}$ Emma Children's Hospital, University of Amsterdam, Amsterdam, The Netherlands \\ ${ }^{2}$ Pediatrics, Wilhelmina Children's Hospital University Medical Centre, Utrecht, The \\ Netherlands \\ ${ }^{3}$ Public and Occupational Health, Amsterdam Public Health Research Institute, VU \\ Medical Center, Amsterdam, The Netherlands \\ ${ }^{4}$ Department of Epidemiology and Biostatistics, University of Amsterdam, \\ Amsterdam, The Netherlands \\ ${ }^{5}$ Paediatrics, Emma Kinderziekenhuis AMC, Amsterdam, The Netherlands
}

Contributors $A B, B S$ and JKvH performed the literature search. $A B$ and $B S$ compiled the tables (including the quality table). $\mathrm{AB}$ and $\mathrm{MWH}$ analysed the data.
$A B$ wrote the first draft of the paper. JKvH, BS, MCP and JBvG critically reviewed the manuscript and provided suggestions. $A B$ finalised the manuscript. All authors have read and approved the final version of this manuscript.

Funding The authors have not declared a specific grant for this research from any funding agency in the public, commercial or not-for-profit sectors.

Competing interests None declared.

Patient consent for publication Not required.

Provenance and peer review Not commissioned; externally peer reviewed.

Data availability statement All data relevant to the study are included in the article or uploaded as supplementary information.

Open access This is an open access article distributed in accordance with the Creative Commons Attribution Non Commercial (CC BY-NC 4.0) license, which permits others to distribute, remix, adapt, build upon this work non-commercially, and license their derivative works on different terms, provided the original work is properly cited, appropriate credit is given, any changes made indicated, and the use is non-commercial. See: http://creativecommons.org/licenses/by-nc/4.0/.

\section{REFERENCES}

1. UNHCR. United nations high Commisioners for refugees, 2018 Available: http://www.unhcr.org/figures-at-a-glance.html

2. Eurostat. Migration and migrant population statistics, 2018. Available: https://ec.europa.eu/eurostat/statistics-explained/index. php?title=Migration_and_migrant_population_statistics

3. Yun K, Matheson J, Payton C, et al. Health profiles of newly arrived refugee children in the United States, 2006-2012. Am J Public Health 2016;106:128-35.

4. Bilukha OO, Jayasekaran D, Burton A, et al. Nutritional status of women and child refugees from Syria-Jordan, April-May 2014. MMWR Morb Mortal Wkly Rep 2014;63:638-9.

5. Geltman PL, Radin M, Zhang Z, et al. Growth status and related medical conditions among refugee children in Massachusetts, 19951998. Am J Public Health 2001;91:1800-5.

6. Stevens GA, Finucane MM, De-Regil LM, et al. Global, regional, and national trends in haemoglobin concentration and prevalence of total and severe anaemia in children and pregnant and non-pregnant women for 1995-2011: a systematic analysis of populationrepresentative data. The Lancet Global Health 2013;1:e16-25.

7. Harteveld CL. Hemoglobinopathy in the Netherlands: an exotic species on clogs. NTVH 2014;11:44-54.

8. Yanni EA, Copeland G, Olney RS. Birth defects and genetic disorders among Arab Americans-Michigan, 1992-2003. J Immigrant Minority Health 2010;12:408-13.

9. Schweitzer A, Horn J, Mikolajczyk RT, et al. Estimations of worldwide prevalence of chronic hepatitis $B$ virus infection: a systematic review of data published between 1965 and 2013. The Lancet 2015;386:1546-55.

10. Marquardt L, Krämer A, Fischer F, et al. Health status and disease burden of unaccompanied asylum-seeking adolescents in Bielefeld, Germany: cross-sectional pilot study. Trop Med Int Health 2016;21:210-8

11. Sheikh M, Pal A, Wang S, et al. The epidemiology of health conditions of newly arrived refugee children: a review of patients attending a specialist health clinic in Sydney. J Paediatr Child Health 2009;45:509-13.

12. Goosen S, Hoebe CJPA, Waldhober Q, et al. High HIV prevalence among asylum seekers who gave birth in the Netherlands: a nationwide study based on antenatal HIV tests. PLoS One 2015;10:e0134724.

13. Organization WH. Global tuberculosis report 2018, 2019. Available: https://www.who.int/tb/publications/global_report/en/

14. Hossain SMM, Leidman E, Kingori J, et al. Nutritional situation among Syrian refugees hosted in Iraq, Jordan, and Lebanon: cross sectional surveys. Confl Health 2016;10:26.

15. Moher D, Shamseer L, Clarke M, et al. Preferred reporting items for systematic review and meta-analysis protocols (PRISMA-P) 2015 statement. Syst Rev 2015;4:1.

16. Yun K, Urban K, Mamo B, et al. Increasing hepatitis B vaccine prevalence among refugee children arriving in the United States, 2006-2012. Am J Public Health 2016;106:1460-2.

17. Hjern A, Stubbe Østergaard L, Nörredam M-L. Health examinations of child migrants in Europe: screening or assessment of healthcare needs? Bmjpo 2019;3:e000411.

18. Shenoda S, Kadir A, Pitterman S, et al. Section on international child $H$. the effects of armed conflict on children. Pediatrics 2018;142. 
19. Schrier L, Wyder C, Del Torso S, et al. Medical care for migrant children in Europe: a practical recommendation for first and followup appointments. Eur J Pediatr 2019.

20. International Organization for Migration EC. Health assessment of refugees and migrants 2015.

21. Prevention CfDCa. Guidelines for the US domestic medical examination for newly arriving refugees. immigrant and refugee health, 2014. Available: https://www.cdc.gov/immigrantrefugee health/guidelines/domestic/domestic-guidelines.html

22. Refugee Health Assessment Recommendations. Recommendations for comprehensive post-arrival health assessment for people from refugee-like backgrounds, 2016. Available: https://www.asid.net.au/ documents/item/1225

23. Pottie K, Greenaway C, Feightner J, et al. Evidence-Based clinical guidelines for immigrants and refugees. Can Med Assoc J 2011;183:E824-925.

24. Canadian Paediatric Society. Canadian paediatric Society. caring for kids new to Canada 2013.

25. Health of resettled Iraqi refugees - San Diego County, California, October 2007-September 2009. MMWR Morb Mortal Wkly Rep 2010;59:1614-8

26. Veldhuijzen IK, Toy M, Hahné SJM, et al. Screening and early treatment of migrants for chronic hepatitis $B$ virus infection is costeffective. Gastroenterology 2010;138:522-30.

27. Usemann J, Ledergerber M, Fink G, et al. Cost-Effectiveness of tuberculosis screening for migrant children in a low-incidence country. Int J Tuberc Lung Dis 2019;23:579-86.

28. Organization BotWH. Revisiting Wilson and Jungner in the genomic age: a review of screening criteria over the past 40 years, 2008. Available: http://www.who.int/bulletin/volumes/86/4/07050112/en/

29. Baauw A, Rosiek S, Slattery B, et al. Pediatrician-experienced barriers in the medical care for refugee children in the Netherlands. Eur J Pediatr 2018.

30. Penrose K, Hunter Adams J, Nguyen T, et al. Vitamin D deficiency among newly resettled refugees in Massachusetts. J Immigr Minor Health 2012;14:941-8.

31. Cohen AL, Rivara F, Marcuse EK. Are language barriers associated with serious medical events in hospitalized pediatric patients? Pediatrics 2005;116:575-9.

32. Bischoff A, Bovier PA, Rrustemi I, et al. Language barriers between nurses and asylum seekers: their impact on symptom reporting and referral. Soc Sci Med 2003:57:503-12.

33. Brandenberger J, Tylleskär T, Sontag K, et al. A systematic literature review of reported challenges in health care delivery to migrants and refugees in high-income countries - the $3 \mathrm{C}$ model. BMC Public Health 2019;19:755.

34. UNHCR. The 1951 convention relating to the status of refugees and its 1967 protocol: office of the high Commisioner for human rights, United nations office at Geneva, 1951. Available: http://www.unhcr. org/about-us/background/4ec262df9/1951-convention-relatingstatus-refugees-its-1967-protocol.htm

35. UNHCR. Asylum seeekers, 2019. Available: https://www.unhcr.org/ asylum-seekers.html

36. Cherian S, Burgner DP, Cook AG, et al. Associations between Helicobacter pylori infection, co-morbid infections, gastrointestinal symptoms, and circulating cytokines in African children. Helicobacter 2010;15:88-97.

37. Gray K, Wood N, Gunasekera H, et al. Vitamin D and tuberculosis status in refugee children. Pediatr Infect Dis J 2012;31:521-3.

38. Lucas M, Nicol P, McKinnon E, et al. A prospective large-scale study of methods for the detection of latent Mycobacterium tuberculosis infection in refugee children. Thorax 2010;65:442-8.

39. Ngo C, Maidment C, Atkins L, et al. Blood screen findings in a 2-year cohort of newly arrived refugees to Sydney, Australia. Public Health Res Pr 2018;28.

40. Paxton GA, Sangster KJ, Maxwell EL, et al. Post-Arrival health screening in Karen refugees in Australia. PLoS One 2012;7:e38194.

41. Sheikh M, Wang S, Pal A, et al. Vitamin D deficiency in refugee children from conflict zones. J Immigrant Minority Health 2011;13:87-93.

42. Trauer JM, Krause VL. Assessment and management of latent tuberculosis infection in a refugee population in the Northern Territory. Medical Journal of Australia 2011;194:579-82.

43. Zwi K, Morton N, Woodland L, et al. Screening and primary care access for newly arrived paediatric refugees in regional Australia: a 5 year cross-sectional analysis (2007-12). J Trop Pediatr 2017:63:109-17.

44. Aucoin M, Weaver R, Thomas R, et al. Vitamin D status of refugees arriving in Canada: findings from the Calgary refugee health program. Canadian Family Physician 2013;59:e188-94.
45. Denburg A, Rashid M, Brophy J, et al. Initial health screening results for Karen refugees: a retrospective review. Can Commun Dis Rep 2007;33:16-22.

46. DeVetten $\mathrm{G}$, Dirksen $\mathrm{M}$, Weaver R, et al. Parasitic stool testing in newly arrived refugees in Calgary, Alta. Can Fam Physician 2017;63:e518-25.

47. Salehi L, Lofters AK, Hoffmann SM, et al. Health and growth status of immigrant and refugee children in Toronto, Ontario: a retrospective chart review. Paediatr Child Health 2015;20:e38-42.

48. Böttcher S, Neubauer K, Baillot A, et al. Stool screening of Syrian refugees and asylum seekers in Germany, 2013/2014: identification of Sabin like polioviruses. Int J Med Microbiol 2015;305:601-6.

49. Heudorf U, Karathana M, Krackhardt B, et al. Surveillance for parasites in unaccompanied minor refugees migrating to Germany in 2015. GMS Hyg Infect Control 2016;11.

50. Heudorf U, Krackhardt B, Karathana M, et al. Multidrug-Resistant bacteria in unaccompanied refugee minors arriving in Frankfurt am main, Germany, October to November 2015. Euro Surveill. 2016;21.

51. Mockenhaupt FP, Barbre KA, Jensenius M, et al. Profile of illness in Syrian refugees: a GeoSentinel analysis, 2013 to 2015 Eurosurveillance 2016;21.

52. Theuring S, Friedrich-Jänicke B, Pörtner K, et al. Screening for infectious diseases among unaccompanied minor refugees in Berlin, 2014-2015. Eur J Epidemiol 2016;31:707-10.

53. Pace-Asciak A, Mamo J, Calleja N. Tuberculosis among undocumented boat migrants to Malta: implications for a migrant tuberculosis policy. Int J Tuberc Lung Dis 2013;17:1065-70.

54. Rungan S, Reeve AM, Reed PW, et al. Health needs of refugee children younger than 5 years arriving in New Zealand. Pediatr Infect Dis J 2013;32:e432-6.

55. Wishart HD, Reeve AMF, Grant CC. Vitamin D deficiency in a multinational refugee population. Intern Med J 2007;37:792-7.

56. Belhassen-García M, Pardo-Lledías J, Pérez del Villar L, et al. Screening for parasite infections in immigrant children from lowincome countries. Enferm Infecc Microbiol Clin 2017;35:27-32.

57. Belhassen-García M, Velasco-Tirado V, Lopez-Bernus A, et al. Nutritional status of children from low-income countries arriving in Spain. Int Health 2017;9:294-300.

58. Stellinga-Boelen AAM, Storm H, Wiegersma PA, et al. Iron deficiency among children of asylum seekers in the Netherlands. J Pediatr Gastroenterol Nutr 2007:45:591-5.

59. Stellinga-Boelen AAM, Wiegersma PA, Bijleveld CMA, et al. Obesity in asylum seekers' children in The Netherlands--the use of national reference charts. Eur J Public Health 2007;17:555-9.

60. Aldridge RW, Zenner D, White PJ, et al. Prevalence of and risk factors for active tuberculosis in migrants screened before entry to the UK: a population-based cross-sectional study. Lancet Infect Dis 2016;16:962-70.

61. Aldridge RW, Zenner D, White PJ, et al. Tuberculosis in migrants moving from high-incidence to low-incidence countries: a population-based cohort study of 519955 migrants screened before entry to England, Wales, and Northern Ireland. The Lancet 2016;388:2510-8.

62. Bennett RJ, Brodine S, Waalen J, et al. Prevalence and treatment of latent tuberculosis infection among newly arrived refugees in San Diego County, January 2010-October 2012. Am J Public Health 2014:104:e95-102.

63. Bennet R, Eriksson M. Tuberculosis infection and disease in the 2015 cohort of unaccompanied minors seeking asylum in northern Stockholm, Sweden. Infect Dis 2017:49:501-6.

64. Brodine SK, Thomas A, Huang R, et al. Community based parasitic screening and treatment of Sudanese refugees: application and assessment of centers for disease control guidelines. Am J Trop Med Hyg 2009;80:425-30.

65. Dawson-Hahn E, Pak-Gorstein S, Matheson J, et al. Growth trajectories of refugee and Nonrefugee children in the United States. Pediatrics 2016;138:e20160953

66. Dawson-Hahn EE, Greenberg SLM, Domachowske JB, et al. Eosinophilia and the seroprevalence of schistosomiasis and strongyloidiasis in newly arrived pediatric refugees: an examination of centers for disease control and prevention screening guidelines. $J$ Pediatr 2010;156:1016-8.

67. Dawson-Hahn EE, Pak-Gorstein S, Hoopes AJ, et al. Comparison of the nutritional status of overseas refugee children with low income children in Washington state. PLoS One 2016;11:e0147854.

68. Kotey S, Carrico R, Wiemken TL, et al. Elevated blood lead levels by length of time from resettlement to health screening in Kentucky refugee children. Am J Public Health 2018;108:270-6.

69. Liu Y, Weinberg MS, Ortega LS, et al. Overseas screening for tuberculosis in U.S.-bound immigrants and refugees. $N$ Engl $\mathrm{J}$ Med 2009;360:2406-15. 
70. Mitchell T, Lee D, Weinberg M, et al. Impact of enhanced health interventions for United States-Bound refugees: evaluating best practices in migration health. Am J Trop Med Hyg 2018;98:920-8.

71. Plotinsky RN, Straetemans M, Wong L-Y, et al. Risk factors for elevated blood lead levels among African refugee children in New Hampshire, 2004. Environ Res 2008;108:404-12.

72. Proue $\mathrm{M}$, Jones-Webb R, Oberg $\mathrm{C}$. Blood lead screening among newly arrived refugees in Minnesota. Minn Med 2010;93:42-6.

73. Shah AY, Suchdev PS, Mitchell T, et al. Nutritional status of refugee children entering DeKalb County, Georgia. J Immigr Minor Health 2014;16:959-67.

74. Stauffer WM, Painter J, Mamo B, et al. Sexually transmitted infections in newly arrived refugees: is routine screening for Neisseria gonorrheae and Chlamydia trachomatis infection indicated? Am J Trop Med Hyg 2012;86:292-5.

75. Taylor EM, Painter J, Posey DL, et al. Latent tuberculosis infection among immigrant and refugee children arriving in the United States: 2010. J Immigr Minor Health 2016;18:966-70.

76. Ugwu C, Varkey P, Bagniewski S, et al. Sero-epidemiology of hepatitis B among new refugees to Minnesota. J Immigrant Minority Health 2008;10:469-74.
77. Varkey P, Jerath AU, Bagniewski S, et al. Intestinal parasitic infection among new refugees to Minnesota, 1996-2001. Travel Med Infect Dis 2007;5:223-9.

78. Varkey P, Jerath AU, Bagniewski SM, et al. The epidemiology of tuberculosis among primary refugee arrivals in Minnesota between 1997 and 2001. J Travel Med 2007;14:1-8.

79. Vitamin B12 deficiency in resettled Bhutanese refugees-United states, 2008-2011. MMWR Morb Mortal Wkly Rep 2011;60:343-6.

80. Walters J, Sullivan A. Early identification and linkage to care of foreign-born people with chronic hepatitis B virus infection, Multnomah County, Oregon, 2012-2014. Public Health Rep 2016;131(2_suppl):105-11.

81. Yanni EA, Naoum M, Odeh N, et al. The health profile and chronic diseases comorbidities of US-bound Iraqi refugees screened by the International organization for migration in Jordan: 2007-2009. J Immigr Minor Health 2013;15:1-9.

82. Zabel EW, Smith ME, O'Fallon A, et al. Implementation of CDC refugee blood lead testing guidelines in Minnesota. Public Health Rep 2008;123:111-6. 